\title{
Educação ambiental na escola: uma ação educativa visando o destino correto dos resíduos sólidos
}

Environmental education in school: an educational action aiming the correct destination of solid waste

\author{
'Henrique José Polato Gomes, Paola Medina"
}

\begin{abstract}
RESUMO
O presente trabalho tem por objetivo verificar se ações educativas surtem algum efeito na compreensão dos conceitos relacionados à reciclagem e conservação do Meio Ambiente. O projeto foi aplicado em turmas do Ensino Fundamental II de um Colégio Estadual de Curitiba, realizando trabalhos de Educação Ambiental voltado para as alternativas corretas do destino do lixo e separação dos materiais recicláveis. A mediação didática foi feita através de um pré-teste para detecção de conhecimentos prévios, uma palestra, cartilha informativa, montagem de um jogo sobre reciclagem e de um pós-teste para verificar a possível mudança dos conceitos. Após a aplicação das mediações, pode-se notar uma melhoria na compreensão dos conceitos, especialmente com a palestra e a cartilha entregue aos educandos. $O$ jogo, embora ajude a despertar $\mathrm{o}$ interesse e seja uma atividade lúdica, não surtiu o efeito esperado, visto que evidenciou que há uma confusão entre os conceitos de reciclagem e reutilização. Palavras-chave: Meio Ambiente. Reciclagem. Sensibilização. Jogo didático. Reutilização.
\end{abstract}

ABSTRACT

The present work aims to verify if educational actions have any effect in the understanding of the concepts related to the recycling and conservation of the Environment. The project was applied in classes of Elementary School of a State College of Curitiba, through an Environmental Education work focused on the correct alternatives of the destination of the trash and separation of the recyclable materials. The didactic mediation was done through a pre-test to detect previous knowledge, a lecture, an informative booklet, the assembly of a game about recycling and a post-test to verify the possible change of the concepts. After applying the mediations, an improvement in the understanding of the concepts is noticeable, especially with the lecture and the booklet given to the students. The game, although it helps to arouse interest and a playful activity, did not have the expected effect, since it showed that there is still a great confusion between the concepts of recycling and reuse.

Keywords: Environment, Recycling, Sensitization, Didactic Game, Reuse.

\section{INTRODUÇÃO}

A Educação Ambiental (EA) visa promover o pensamento crítico e reflexivo na sociedade atual, contribuindo através do Ensino de Ciências e outras disciplinas, visto que todas estão relacionadas a esta área do conhecimento, para a formação de novos valores e conhecimentos. Isso possibilita a sensibilização das pessoas para o exercício da cidadania, tornando-as mais responsáveis, solidárias e comprometidas com o coletivo, colaborando para um planeta mais sustentável. (JACOBI, 2005).

Atualmente o termo sustentabilidade, associado ao desenvolvimento, vem sendo discutido no mundo todo; porém, mesmo com todas essas discussóes relacionadas às questôes socioambientais, não é possível enxergar a conscientização dos governos, empresas e mesmo pela maior parte da população. (SILVA et al., 2013).

Segundo Rodrigues (1997), "a interaçấo entre os homens e o ambiente ultrapassou a questâo de simples sobrevivência”. Com a urbanização e evolução da civilização, a percepção do ambiente mudou e a natureza passou a ser entendida como algo separado e inferior à sociedade humana, ocupando uma posiçáo de subserviência. No decorrer do século passado, para se atender as necessidades humanas foi-se desenhando uma equação desbalanceada: retirar, consumir e destacar. (MADEIRA, 2009).

A Política Nacional de Resíduos Sólidos instituída por meio da lei No 12.305, de 2 de agosto de 2010, 
versa sobre as disposiçôes corretas do lixo e da responsabilidade de cada cidadão na separação correta dos resíduos sólidos, de forma que subsidia o enfrentamento dos principais problemas ambientais, sociais e econômicos que ocorram pelo manejar inadequado destes resíduos (BRASIL, 2010).

Entretanto, mesmo com as disposiçóes legais e as consequências da deposição inadequada dos resíduos sólidos não é incomum encontrar esses resíduos sem qualquer forma de separação e/ou dispostos inadequadamente. Se for considerado que a conservação e preservaçáo do meio ambiente não podem ser encaradas sem levar em conta o comportamento e as açôes dos seres humanos, levanta-se o questionamento se a desinformação não seria um fator preponderante nessa disposição incorreta e, de certa forma, irresponsável (OLIVEIRA, 2006).

Assim, a intenção desse trabalho é verificar a percepção de estudantes sobre a temática do reuso e da reciclagem e verificar se uma ação educativa tem efeito na mudança da concepçáo e, futuramente, das atitudes no que tange à disposição e separação dos resíduos sólidos.

\section{REFERENCIAL TEÓRICO}

\section{I ReSíDUOS SÓLIDOS}

O crescente aumento do uso de recursos e a consequente produção de resíduos, refletem a necessidade de, além da redução e da reutilização, do tratamento adequado dos resíduos descartados. Em média, as populaçôes humanas tendem a consumir cerca de $30 \%$ a mais do que o planeta pode naturalmente repor, além de haver uma pronunciada desigualdade no acesso a esses recursos (CEMPRE, 2013). Por exemplo, os estadunidenses geram cerca de dois quilogramas de resíduos sólidos por habitante ao dia, ao passo que os japoneses, também em média, de elevado poder aquisitivo, apresentam comportamentos que resultam em cerca de um quilograma por habitante por dia. Os brasileiros, por sua vez, mesmo com renda per capita significativamente menor, ficam próximos aos níveis japoneses (ABRELPE, 2008), o que mostra como o Brasil possui os altos índices de geração de resíduos, considerando a realidade financeira da média da população. No ano de 2016, a disposição final correta dos resíduos sólidos coletados demonstrou ligeira piora se comparado ao índice do ano anterior, de 58,7\%, para 58,4\%, o que representa 41,7 milhóes de toneladas enviadas para aterros sanitários. Ainda assim, embora $91 \%$ dos resíduos sólidos urbanos sejam coletados, talvez o dado mais alarmante seja que 41,6\% (29,7 milhões de toneladas) do lixo coletado ainda são enviados para lixóes ou aterros controlados, que náo possuem o conjunto de sistemas e medidas necessários para proteçáo do meio ambiente contra danos e degradaçôes (ABRELPE, 2016).

A definição de "lixo" é muito contextual e transitória. Atualmente, o conceito não pode ser mais sinônimo de um resto ou detrito inútil, mas sim como algo que, se corretamente dispostos, pode ser transformado em nova matéria-prima e retornar ao ciclo produtivo (Ministério do Meio Ambiente, 2005). Por isso, opta-se pelo termo "resíduo sólido" ao invés do termo "lixo".

A já citada Lei no 12.305, que institui a Polícia Nacional de Resíduos Sólidos (PNRS), em seu art. 30, XVI, define "resíduo sólido" como todo material, substância, objeto ou bem descartado resultante de atividades humanas em sociedade, a cuja destinação final se procede, se propóe proceder ou se está obrigado a proceder, nos estados sólido ou semissólido, bem como gases contidos em recipientes e líquidos cujas particularidades tornem inviável o seu lançamento na rede pública de esgotos ou em corpos d'água, ou exijam para isso soluçôes técnica ou economicamente inviáveis em face da melhor tecnologia disponível (BRASIL, 2010; FILHO et al., 2015). No entanto, ainda há uma série de problemas na logística reversa e na responsabilidade compartilhada entre sociedade, governo e indústria que fazem com a destinação e a disposição dos resíduos permaneça sendo feita de forma muito incorreta. (FILHO et al., 2015).

\subsection{EducaÇÃo Ambiental}

Quando se trata de Meio Ambiente em uma abordagem pedagógica percebe-se a importância dessa consciência ambiental trabalhada no espaço escolar, porém quanto ao conceito "Meio Ambiente" observa-se que ainda é confuso com diferentes interpretaçóes por parte dos discentes (CABRAL et al., 2015).

Nesse projeto, para definir o espaço e o contexto que rodeiam um ser, será utilizado o termo "Meio Ambiente" com a mesma ideia de Maranhão (2016), o qual diz que:

É possível concluir que ambiente tem conotação mais estática, fotográfica, alusiva à descrição e captação dos fatores naturais e humanos que nos envolvem e nos circundam. Meio ambiente, por outro lado, é conceito mais rico e de conotação mais requintada, expressando uma noção ligada às ideias de interdependência e dinamicidade. 
A partir da Revoluçáo Industrial, gerando o modelo de desenvolvimento fabril com o advento da máquina a vapor, houve uma intensificação a degradação do Meio Ambiente, provocando o aumento dos problemas socioambientais: o esgotamento de recursos naturais, a destruição do ecossistema, perda da biodiversidade, entre outros problemas (GUERRA, 2009).

O fato do ser humano não relevar as consequências de suas açóes sobre o meio, tem levado a uma crescente deterioração do ambiente numa escala global. Segundo Dias (1994), "os recursos da Terra são suficientes para atender as necessidades de todos os seres vivos do planeta, se forem manejados de forma eficiente e sustentada".

A Educação Ambiental, em razão da complexidade das questóes ambientais deve ser desenvolvida ou tratada na escola, sob uma abordagem multi e interdisciplinar. Segundo Fazenda (1993), "o ensino interdisciplinar nasce da proposição de novos objetivos, de novos métodos, de uma nova pedagogia e a instauração de uma prática dialógica, eliminando as barreiras entre as disciplinas e entre as pessoas que pretendem desenvolvê-las".

De acordo com Wojciechowski (2006):

O saber ambiental deve ir se construindo desde a infância, respeitando os níveis de maturidade dos educandos, partindo da experiência concreta com o meio físico e social, procurando soluçôes para os problemas socioambientais locais. Para isso, há a necessidade de se criar, na escola, um contexto dialógico de saberes e conhecimentos, que problematize os paradigmas estabelecidos, objetivando a construçáo de uma nova racionalidade socioambiental, que não se submeta simplesmente aos desígnios de um mundo capitalista.

A escola é o local propício para a introdução de novas ideias e aprendizagens; portanto, ela tem um papel primordial na construção e nas mudanças de atitudes do homem, além de servir de suporte para despertá-lo da consciência a respeito dos problemas através de um ensino ativo e participativo. Segundo Vasconcelos \& Vilarouca (2010), "na EA o ambiente deve ser visto em todos os seus aspectos, atividades de EA devem ocorrer dentro e fora da escola, o aluno além de conhecer os ambientes da escola, deve entender suas açóes ao entorno e em todos os níveis de ensino".

$\mathrm{Na}$ visão dos Parâmetros Curriculares Nacionais do Meio Ambiente (1997):

A Educaçáo Ambiental deve ser desenvolvida com o intuito de auxiliar os estudantes a desenvolverem uma consciência do meio em que vivem, para que possam adquirir uma posição que tragam melhoria e preservação ao meio. É necessário que conheçam através da perspectiva ambiental os problemas que afetam desde sua vida até o planeta em sua totalidade.

A Lei da Educação Ambiental, em seu Art. $2^{\circ}$ afirma (1999), "a Educação Ambiental é um componente essencial e permanente da educação nacional, devendo estar presente, de forma articulada, em todos os níveis e modalidades do processo educativo, em caráter formal e não formal".

A Educação Ambiental, precisa ser entendida como uma importante aliada do currículo escolar na busca de um conhecimento integrado que supere a fragmentaçáo, uma vez que ela sustenta todas as atividades e impulsiona os aspectos físicos, biológicos, sociais e culturais dos seres humanos, o seu alcance deve ser ampliado para que não se limite aos processos formais de ensino, mas envolva, um amplo conjunto de práticas sociais e educativas que possa se desenvolver fora da escola, caracterizando-a como uma Educaçáo Ambiental de caráter popular (CABRAL et al., 2015).

A EA deve estar presente em todo o currículo escolar, visto que está relacionada a todas as áreas do conhecimento, promovendo reflexóes e açóes acerca dos problemas ambientais que a sociedade enfrenta. Para que essas reflexôes possam tornar-se significativas aos alunos, é necessário que tenham como ponto de partida, os problemas socioambientais que vivem e se encontram dentro do ambiente escolar, que possam repensar e se sensibilizarem sobre a problemática ambiental a partir da escola, assim proporcionando na comunidade, ações de melhoria na qualidade de vida.

Nesta perspectiva, A EA apresenta um caráter interdisciplinar, em que sua abordagem deve ser contínua e integrada. De acordo com a Lei da Educação Ambiental (1999), "a Educaçáo Ambiental não deve ser implantada como uma disciplina no currículo de ensino em conformidade com a lei 9.795/99".

Reciclar é o processo mais eficiente e ecologicamente responsável no trato dos resíduos. Ao reciclar, se faz com que o material volte ao ciclo produtivo e evita a produção de um novo material que demandaria uma grande extração de matéria-prima. (OKIDA, 2006). 
Deve-se enfatizar a educação e conscientização no ambiente escolar com ações voltadas à diminuição de resíduos, conservação do Meio Ambiente, construção de uma sociedade sustentável, usufruindo do nosso ambiente de forma responsável, preservando para que as futuras geraçôes possam usufruir do ecossistema local. Conforme afirma Freire (2002):

O lixo é composto de resíduos de nossa cultura, de objetos que não são mais utilizados. No entanto, estes objetos podem readquirir valor nas mãos das crianças. Se bem utilizado, pode servir também como material pedagógico. Principalmente no ensino fundamental, trabalhos com reciclagem do lixo podem contribuir na conscientização dos alunos em relação ao uso racional dos recursos naturais.

Para que a aprendizagem seja mais significativa, um jogo didático, por exemplo, é uma ferramenta metodológica interessante, considerando que ele facilita o entendimento e desperta o interesse através do lúdico. De acordo com Pinto (2009):

Quando um tema de grande relevância, como o meio ambiente, não consegue sensibilizar o jovem, seja por uma questáo de experiência de vida ou de amadurecimento, esse assunto torna-se sem grande significado em seu dia a dia. Isso também pode acontecer com a não correta utilização dos jogos didáticos, que passa a ter apenas um valor lúdico e, não, de construção de conhecimento.

Os estudantes devem entender que eles podem reciclar com atitudes simples, porém, importantes para o ser humano e para o Meio Ambiente. Adotar decisóes mais ecológicas e rever as atitudes do seu dia a dia, mostrando na prática que a reciclagem pode evitar a destruiçáo do nosso planeta, preservando o Meio Ambiente, assim, preservando o futuro (MEDEIROS et al., 2011a)

É escopo do presente trabalho fazer com que esses alunos percebam a importância da preservaçáo dos recursos naturais, da necessidade da mudança de hábitos visando à conservaçáo do Meio Ambiente e que todos compreendam que esses problemas têm impactos em toda a sociedade. (MEDEIROS et al., 2011b).

Assim, este projeto foi realizado em uma escola da Rede Estadual do Paraná, visando a importância da sensibilização dos alunos de como se preservar o meio ambiente através da reciclagem. O objetivo do presente trabalho, portanto, é verificar se, através de intervençóes didáticas como palestras, diálogos e vídeos, é possível melhorar a compreensão dos estudantes sobre a importância e sobre o próprio conceito de reciclagem, além de sensibilizá-los sobre a importância da preservação e da reciclagem. Essas mediaçóes didáticas foram elaboradas com base nas respostas de um questionário usado como pré-teste, o qual também foi aplicado após as intervençóes para verificar a mudança de pensamento. Finalmente, foi proposta a elaboração de jogos que deveriam evidenciar os conceitos aprendidos.

\section{METODOLOGIA}

Com o intuito de passar para os estudantes a importância da reciclagem como um dos fatores importantes para conservaçáo do Meio Ambiente, esse projeto foi aplicado com, cerca de uma aula por semana para que o andamento do conteúdo programático fosse respeitado, durante dois meses em uma Escola Estadual do Paraná, na região metropolitana de Curitiba. Assim, 94 alunos dos $6^{\text {os }}$ e $7^{\text {os }}$ anos do Ensino Fundamental, com média de idade de 11,5 anos e representando um universo de $48 \%$ da escola.

\section{I APLICAÇÃo do QUESTIONÁRIO de CONHECIMENTOS PRÉVIOS}

Essa pesquisa, portanto, tem caráter descritivo e se fundamentou em uma metodologia de observação e de aplicação de pré e pós-testes parar verificação da aprendizagem e da mudança de conceitos antes e depois das intervençôes pedagógicas. Assim, a metodologia inicialmente utilizada foi à aplicação de um questionário sobre verdades e mentiras do que se pode ou não ser reciclado, buscando analisar o grau de conhecimento prévio dos alunos sobre o tema no início do projeto. Os mesmos foram instruídos a responder anonimamente o questionário, recebendo apenas informaçôes referentes à interpretação das questôes; não foi dada nenhuma orientaçáo sobre resíduos ou reciclagem para evitar qualquer influência ou enviesamento. A escolha das questóes se centrou em equívocos cotidianos e noçóes de senso comum que nem sempre estáo cientificamente corretas; além disso, foram privilegiadas questóes de caráter mais objetivo e de respostas mais assertivas, evitando exceçóes e favorecendo a tabulação dos dados. O questionário aplicado pode ser visto na figura 1. 


\subsection{INTERVENÇÕES PEDAGÓGICAS}

Com base nos erros identificados no questionário, o assunto foi abordado na forma de palestras dialogadas, com temas que abordaram predominantemente: ambiente, alternativas corretas do destino do lixo e separaçáo de materiais recicláveis.

Após isto, foi passado aos alunos um trecho do documentário baseado no livro homônimo "A História das Coisas" (Story of Stuff- LEONARD, 2011), onde se trata sobre a extração, produção, consumo, descarte e venda de uma série de bens de consumo. Considerando que o mesmo é baseado nos padróes de consumo, moda, publicidade, e como a mídia exerce sua influência sobre as pessoas, muitas informaçóes podem ser evidenciadas no que tange às conexôes entre diversos problemas ambientais e sociais. O objetivo era levantar o questionamento se há alternativas e como fazer para amenizar esse impacto, levando a um alerta pela urgência em criarmos um mundo mais sustentável e justo. Após a exibição, foi aberta uma roda de conversa, onde os alunos expuseram suas impressóes e opiniōes.

Depois do debate e das dúvidas sanadas, foi elaborada e entregue aos estudantes, uma cartilha informativa de como se reciclar corretamente, mostrando a preocupaçáo sobre a importância de conservação do Meio Ambiente e diminuição dos resíduos. Originalmente, a intenção era que essa cartilha fosse entregue diretamente para pais e/ou responsáveis em uma reuniáo informativa que ocorre periodicamente na escola. No entanto, essa reunião acabou não acontecendo no mês em questão, de forma que a mesma foi repassada diretamente aos alunos após a mediação na forma de palestra. Ainda assim, foi reforçado o intuito de que essa cartilha seja compartilhada com os familiares, amigos e a comunidade como um todo, possibilitando que estes também compreendam a importância da reciclagem, bem como a maneira correta da destinação dos resíduos.

Figura 1 - Questionário aplicado para verificação de conhecimentos prévios.

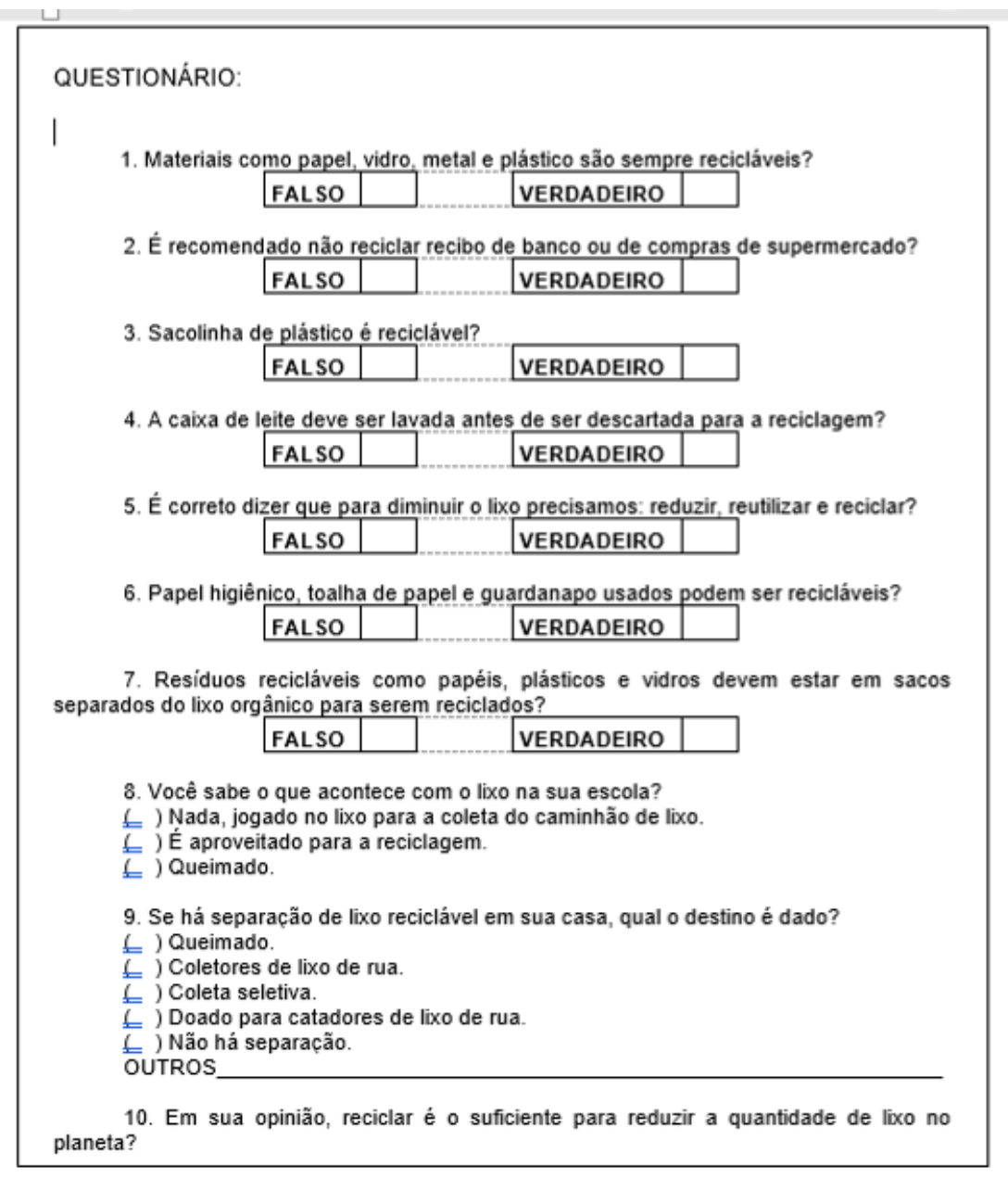

Fonte: Os autores, 2018. 


\subsection{JOGO DIDÁTICO}

Por último, os alunos foram orientados a desenvolverem um jogo didático que tratasse dos assuntos abordados, também utilizando materiais recicláveis. Isso foi feito com o intuito de deixar o ensino de Ciências mais prazeroso, fazendo com que, por meio do lúdico, os alunos mudem seus hábitos e atitudes e continuem realizando a EA não somente dentro do ambiente escolar. Além disso, foi conseguir avaliar os conhecimentos sem o caráter formal de uma avaliação tradicional. De acordo com Macedo (2009), os jogos são um instrumento, que podem muito bem ser utilizados como um método eficaz de avaliação. Através deles é possível analisar qualitativamente os procedimentos e registros discentes em diferentes situaçóes de aprendizagem além de complementarem o conteúdo teórico e aumentarem a interação entre conhecimento-professor-aluno (MACEDO et al.,2009).

Assim, os alunos trouxeram material reciclável e, durante duas aulas puderam montar os jogos livremente, sem direcionamento para algum tipo específico de material. $\mathrm{Na}$ aula seguinte, eles tiveram a oportunidade de jogarem os jogos uns dos outros, visando maximizar o conhecimento, dentro da ludicidade relacionada a diferentes jogos.

\subsection{NOVA APLICAÇÃO DO MESMO QUESTIONÁRIO INICIALMENTE APLICADO.}

Finalmente, após todas as etapas, foi aplicado o mesmo questionário aplicado anteriormente, para que o mesmo funcionasse como um pós-teste, avaliando se houve melhoria na compreensão dos alunos no decorrer do desenvolvimento das atividades.

Os resultados foram tabulados e estão dispostos abaixo, de forma comparativa, visando verificar a efetividade das mediaçôes didáticas aplicadas.

\section{RESULTADOS E DISCUSSÃO}

Como exposto anteriormente, para verificar os conhecimentos prévios dos alunos, foi aplicado um questionário para duas turmas de $6^{\circ}$ ano e uma turma de $7^{\circ}$ ano e os resultados obtidos foram:

$\mathrm{Na}$ primeira pergunta do questionário, a intenção era verificar se acreditavam que um material tradicionalmente conhecido por ser reciclável, realmente sempre pode ser reciclado. Esse é um erro comum, visto que materiais contaminados ou com determinados usos específicos, como lenço de papel, papel higiênico, lâminas de barbear, esponjas de aço, clipes, entre outros, comumente náo podem ser reciclados. As respostas para essa pergunta encontram-se na figura 2.

Figura 2 - Resposta para a pergunta 1: "Materiais como papel, vidro, metal e plástico são sempre recicláveis?”.

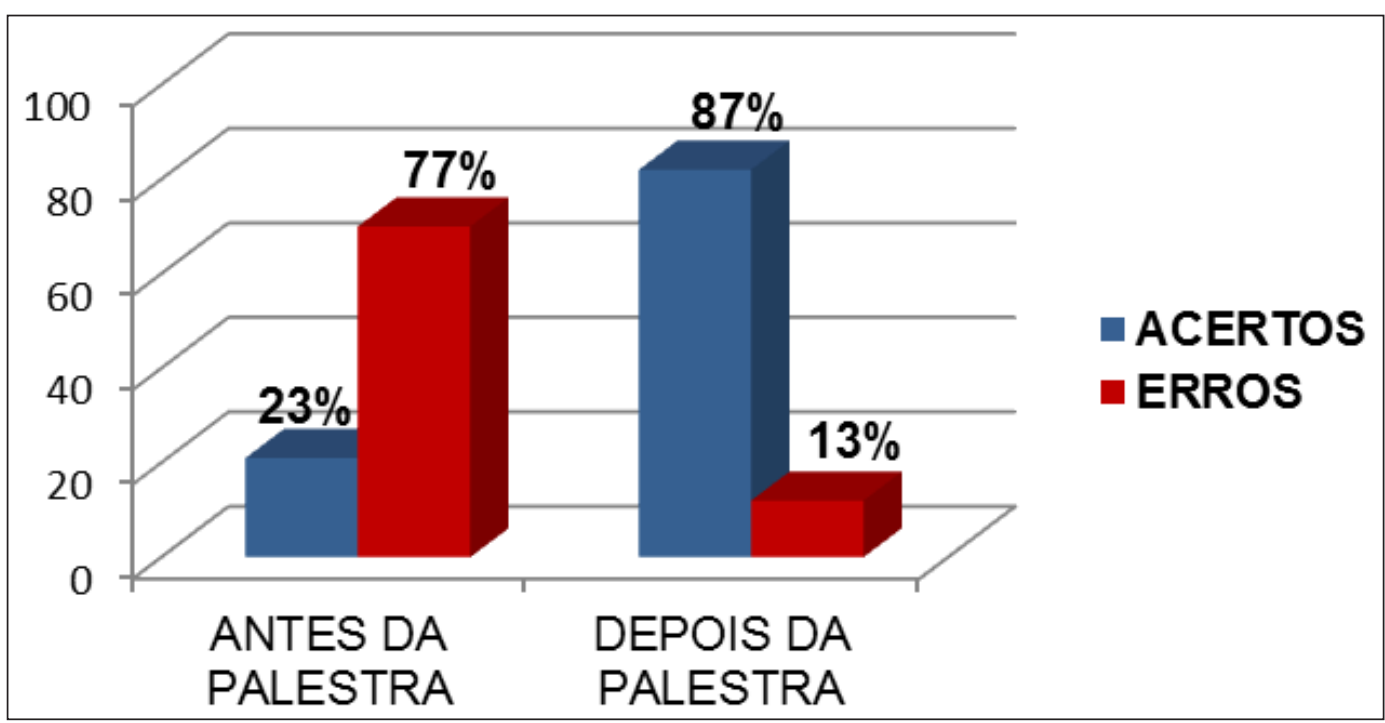

Fonte: Os autores, 2018.

Percebe-se que no primeiro momento, esse erro, típico do senso comum, em que os materiais são peremptoriamente classificados em recicláveis ou não, independentemente da situação, aparece em grande número. Após 
a palestra, é notório que houve a melhoria na compreensão dos alunos, visto que é um erro comum acreditar que esses materiais poderão ser reciclados sempre.

O objetivo da segunda pergunta, era analisar o conhecimento dos alunos em relação aos recibos ou comprovantes de bancos e mercados, visto que, estes papéis térmicos (recibos e comprovantes) parecem inofensivos e se assemelham a um papel comum. No entanto, segundo (MELZER et al., 2011), "apresentam em sua composição pequenas quantidades de Bisfenol-A (BPA), que é potencialmente nocivo à saúde". O BPA é um xenoestrógeno, ou seja, uma substância que confunde os receptores celulares no organismo e se comporta de forma parecida à dos estrógenos naturais. Essas substâncias, de maneira geral desequilibram o sistema endócrino, reprodutor e nervoso central (OLIVEIRA et al., 20017).

A contaminação pelos papéis térmicos pode ocorrer através do contato com a pele. Apesar deste tipo de papel ser reciclável, é recomendado que seja descartado no lixo comum para evitar que durante o processo de reciclagem não contamine outros produtos recicláveis, devido à presença de BPA em sua composição. As respostas para essa pergunta encontram-se na figura 3.

Figura 3 - Resposta para a pergunta 2: "É recomendado não reciclar recibo de banco ou de compras de mercado?"

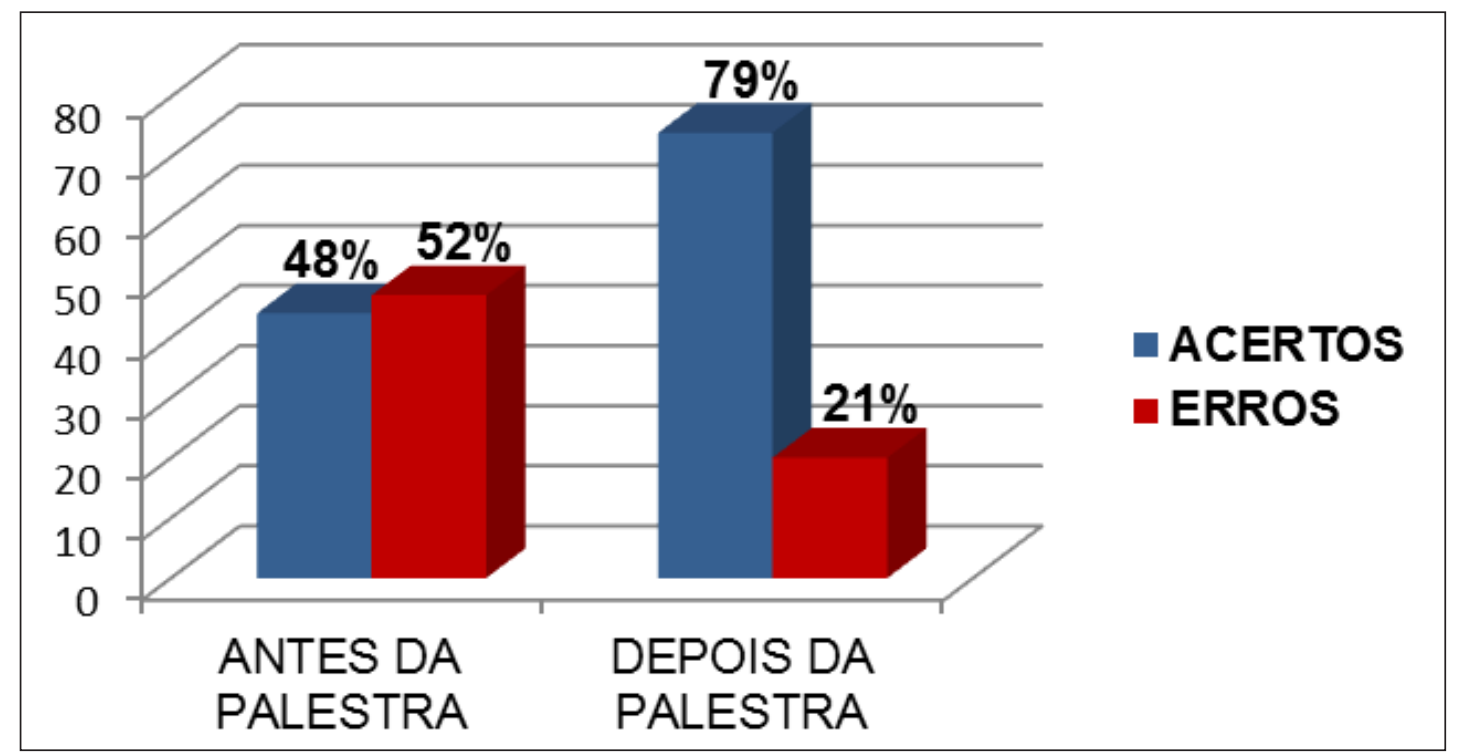

Fonte: Os autores, 2018.

Nesse caso, percebe-se que não houve um erro de interpretação ou um equívoco semelhante ao da primeira pergunta, mas sim a falta de conhecimento sobre o tema. Analisando as respostas, pode-se dizer que o mesmo foi melhor compreendido após a palestra.

$\mathrm{Na}$ pergunta de número três, a intenção era analisar se os alunos acreditavam que um material táo comum como sacola plástica pode ser reciclável. A resposta é afirmativa; no entanto, devido ao fato de que muitos materiais são contados por massa, a sacola plástica leva desvantagem econômica devido a sua leveza. Isso suscita a discussão sobre o fato que, em algumas situaçôes, a reciclagem do produto pode não se tornar economicamente viável por razóes como: a dificuldade de sua separação, a dificuldade de limpeza ou descontaminação ou mesmo a fina espessura e baixa massa do material. O ideal é reduzir o uso desse tipo de material e reaproveitá-lo ao máximo no nosso dia a dia, antes de descartá-lo. As respostas para esta pergunta encontram-se na figura 4 e, após sua análise, é possível verificar que houve um pequeno aumento do número de acertos após a palestra, provavelmente porque os alunos já possuíam um conhecimento sobre a reciclabilidade das sacolas plásticas, já que este material é comum e o seu potencial de reciclagem é tratado com relativa frequência no dia a dia dos consumidores em geral

Na pergunta quatro, o objetivo era analisar o conhecimento dos alunos em relação a lavagem de produtos recicláveis. Em tese, para reciclagem ocorrer, é necessário que os materiais estejam limpos, assim, evitando odores, a contaminação de outros itens recicláveis que estejam no local e surgimento de animais como, ratos e baratas. Contudo, desperdiçar uma quantidade considerável de água para fazer essa limpeza, fato que se mostra 
Figura 4 - Resposta para a pergunta 3 do questionário: "Sacola de plástico é reciclável?"

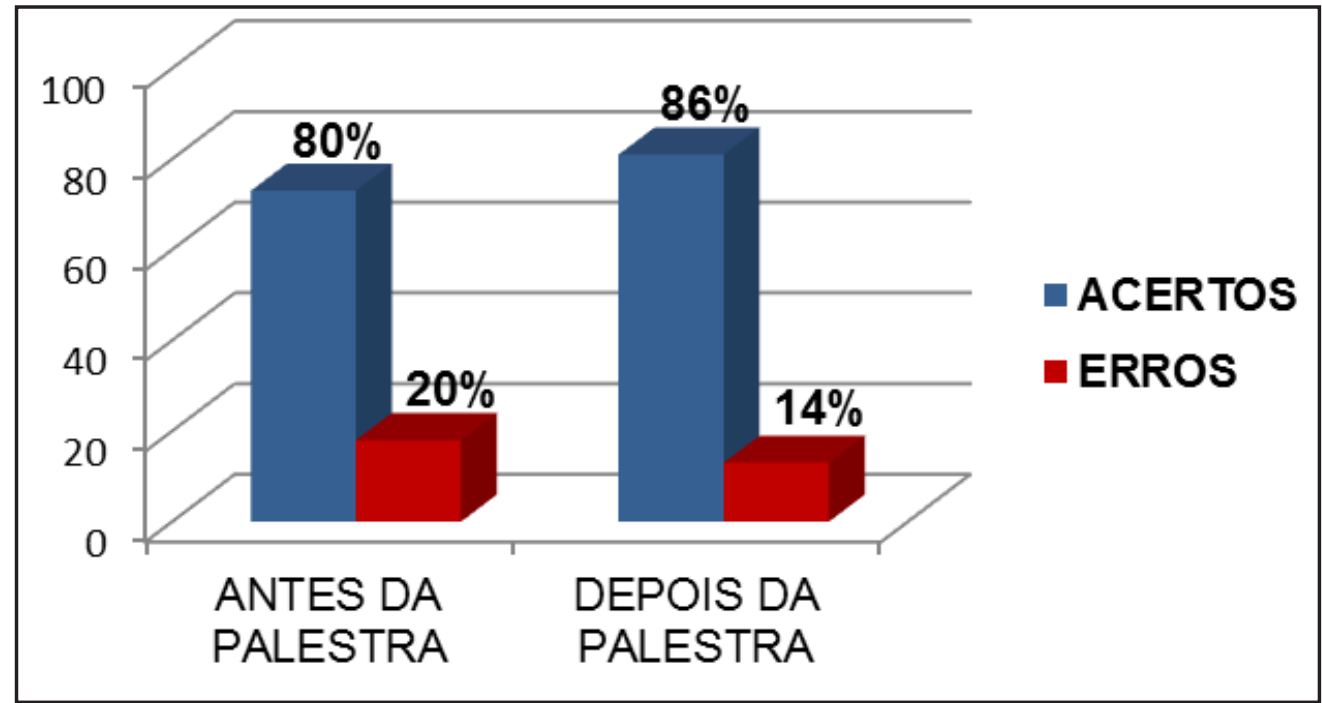

Fonte: Os autores, 2018

pouco sensato devido à escassez desse recurso, realmente não é o correto. Então, talvez o ideal seria reutilizar a água utilizada para lavar louça, da chuva, da fervura de alimentos, por exemplo. As respostas podem ser vistas na figura 5.

Figura 5 - Resposta para a pergunta 4: "A caixa de leite deve ser lavada antes de ser descartada para a reciclagem?"

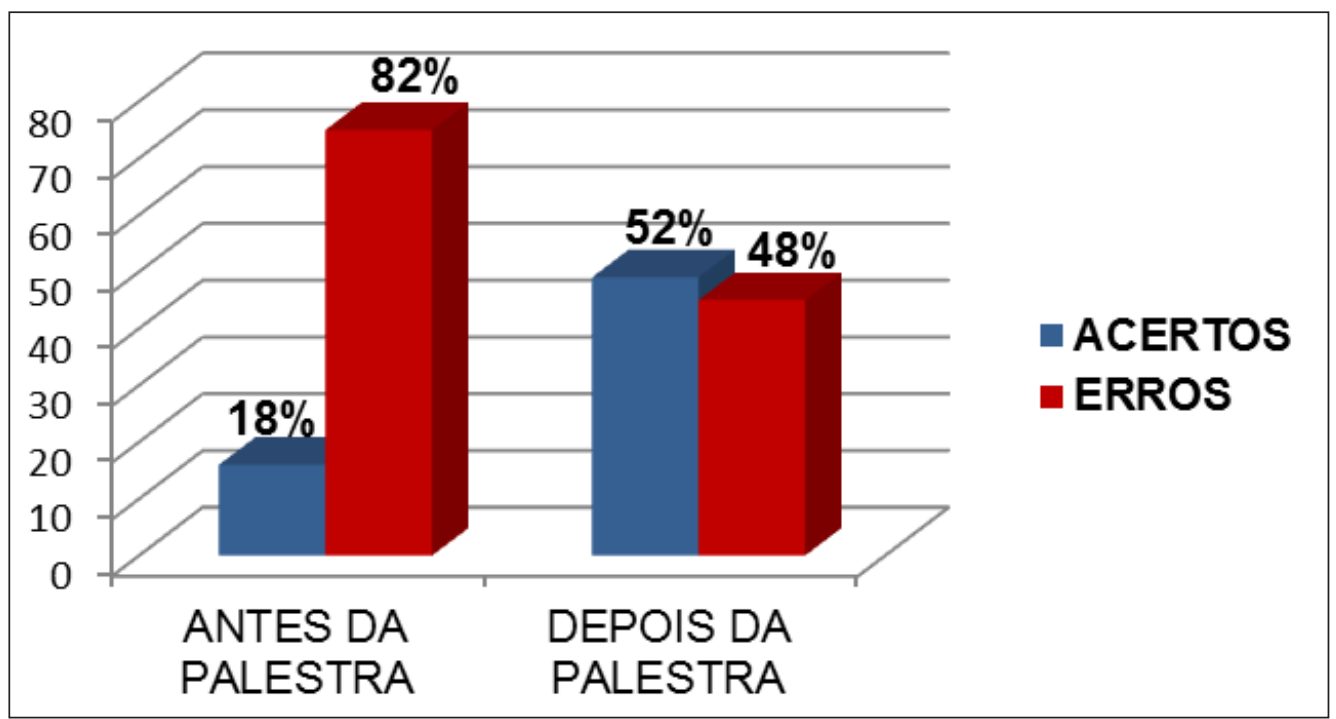

Fonte: Os autores, 2018

Após a palestra, pode-se perceber que diminuíram os erros com relação a este equívoco comum, no qual as pessoas acham que os materiais devem estar limpos para poderem ser recicláveis e para isto, devem ser lavados, o que não é necessariamente verdade. Este estando limpo e sendo descartado no seu local correto é o ideal. Vale ressaltar que o objetivo era que eles percebessem que o material precisa estar limpo, mas não precisa ser lavado com água potável. É possível que a pergunta inicial tenha induzido ao erro, mas isso só foi percebido após a aplicação do questionário.

$\mathrm{Na}$ quinta pergunta, a intenção foi verificar se os alunos sabem as principais pequenas açôes essenciais que qualquer cidadão responsável pode, e deve seguir para contribuir com o Meio Ambiente. Diante deste fato, deve-se pensar na pedagogia dos $3 \mathrm{R}^{\prime}$ s: reduzir, reutilizar e reciclar, pois são importantes alternativas para a redução da quantidade de resíduos, aumentando o tempo de vida dos aterros sanitários, economizando matéria prima, energia entre outros. Além dos $3 \mathrm{R}^{\prime}$ s podem ser adicionados mais $2 \mathrm{R}^{\prime} \mathrm{s}$ totalizando 5 R's (SILVA et al., 
2017), sendo eles refletir, recusar, reduzir, reutilizar e reciclar. Deve-se refletir, portanto, sobre os nossos hábitos de consumo, recusar produtos que prejudicam o meio ambiente e a saúde, reduzir o consumo desnecessário, reutilizar o máximo antes de descartar e por fim reciclar os materiais (ANTQUEVES et al., 2015).

As respostas para essa questão encontram-se na figura 6

$\mathrm{Na}$ questão seis, o objetivo era verificar se os alunos acreditavam que materiais como papéis higiênicos, toalhas de papel e guardanapos que, em princípio, são recicláveis, depois de usados também poderiam ser reciclados. A resposta, de maneira geral, é não; após o uso, esses materiais passam a ser inadequados não somente para o manuseio, mas também para os processos de reciclagem e para a fabricação de outros tipos de papéis. Esse material, portanto, deve ser descartado no lixo comum, pois ao entrarem em contato com qualquer resíduo orgânico, como restos de alimentos e gordura, perdem consideravelmente sua reciclabilidade e ainda podem contaminar outros materiais que poderiam ser reciclados. As respostas para essa questão encontram-se na figura 7 .

Figura 6 - Resposta para a pergunta 5: "É correto dizer que para diminuir o lixo precisamos principalmente: reduzir, reutilizar e reciclar?".

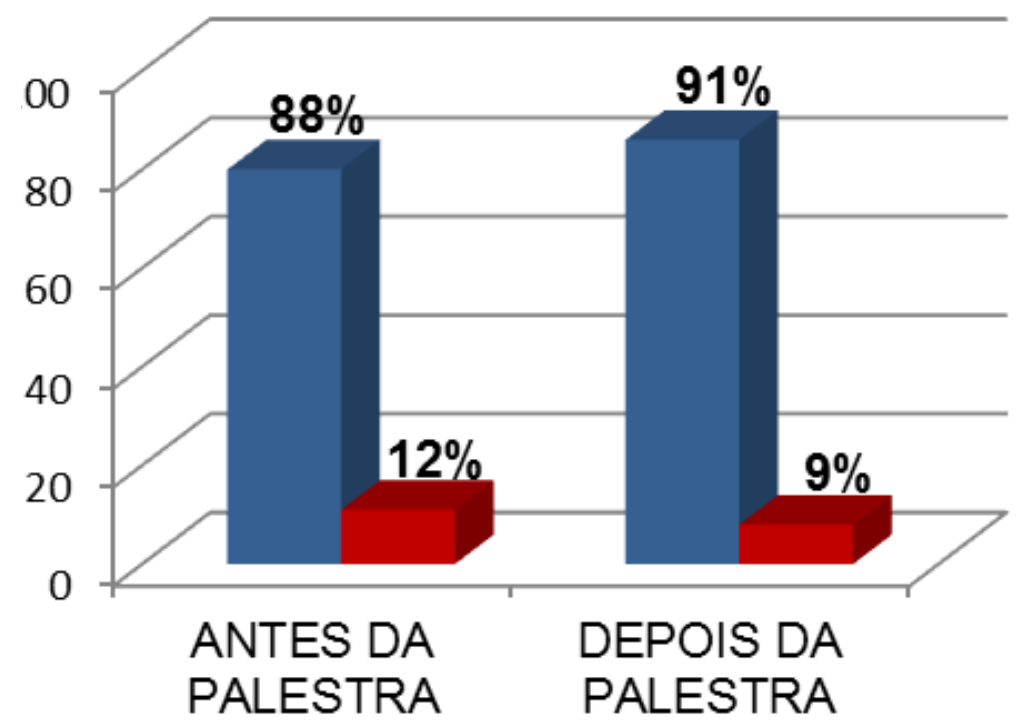

- ACERTOS - ERROS

Fonte: Os autores, 2018.

Figura 7 - Resposta para a pergunta 6: "Papel higiênico, toalha de papel e guardanapo usados podem ser recicláveis?”.

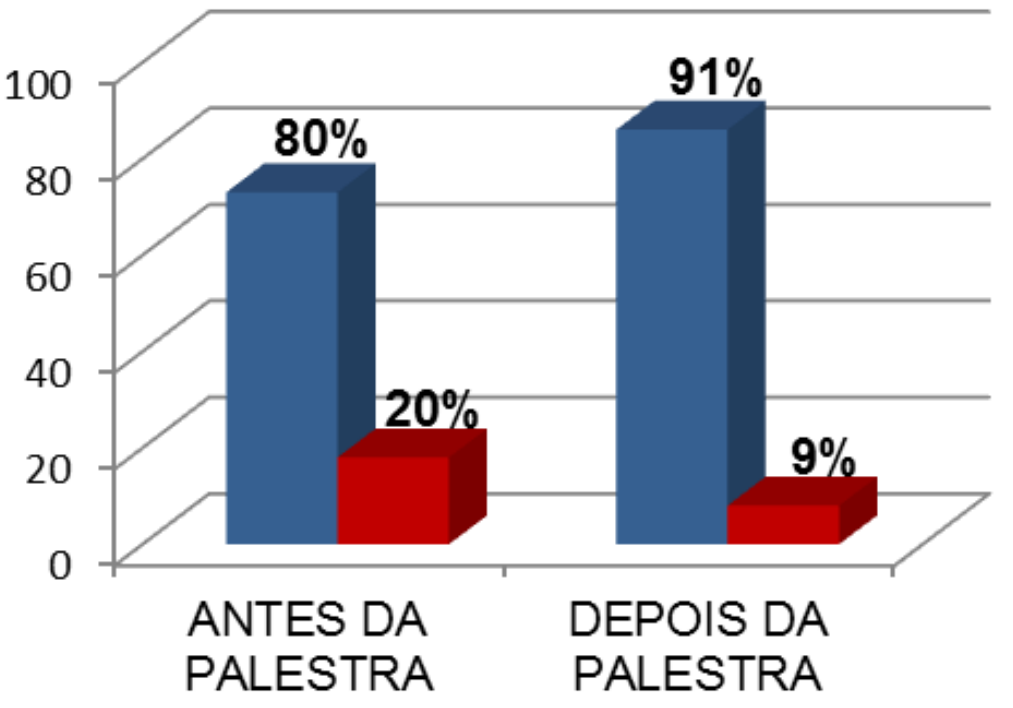

Fonte: Os autores, 2018 .

\section{ACERTOS ERROS}


Houve uma melhoria nesta questão após a palestra, mas é notório que os alunos já tinham um conhecimento prévio a respeito da inutilidade dos materiais após serem utilizados. O objetivo do questionário era reconhecer os conhecimentos prévios e ficou claro que eles já possuíam conhecimento sobre esse tema.

A intenção da pergunta sete foi verificar se os alunos sabem o que se fazer com o os resíduos recicláveis e orgânicos. O correto seria fazer a separação de cada material reciclável em sacos, ou recipientes, diferentes; porém, se não for possível este tipo de separação em casa, ela deveria ser feita diretamente nos postos de reciclagem.

Porém, o lixo orgânico deve estar totalmente separado dos materiais a serem reciclados. O destino correto para o material orgânico é a entrada no processo de ciclagem de nutrientes, podendo ser utilizados como fonte de matéria orgânica, diretamente na terra; ou ainda, se possível, investir em uma composteira doméstica, que seria a soluçáo adequada para se reduzir o volume do lixo orgânico, consequentemente reduzindo o volume de lixo enviado aos lixões e aterros sanitários. As respostas encontradas para essa questão encontram-se na figura 8.

Figura 8 - Resposta para a pergunta 7: "Resíduos recicláveis como papéis, plásticos e vidros devem estar em sacos separados do lixo orgânico para serem reciclados?”.

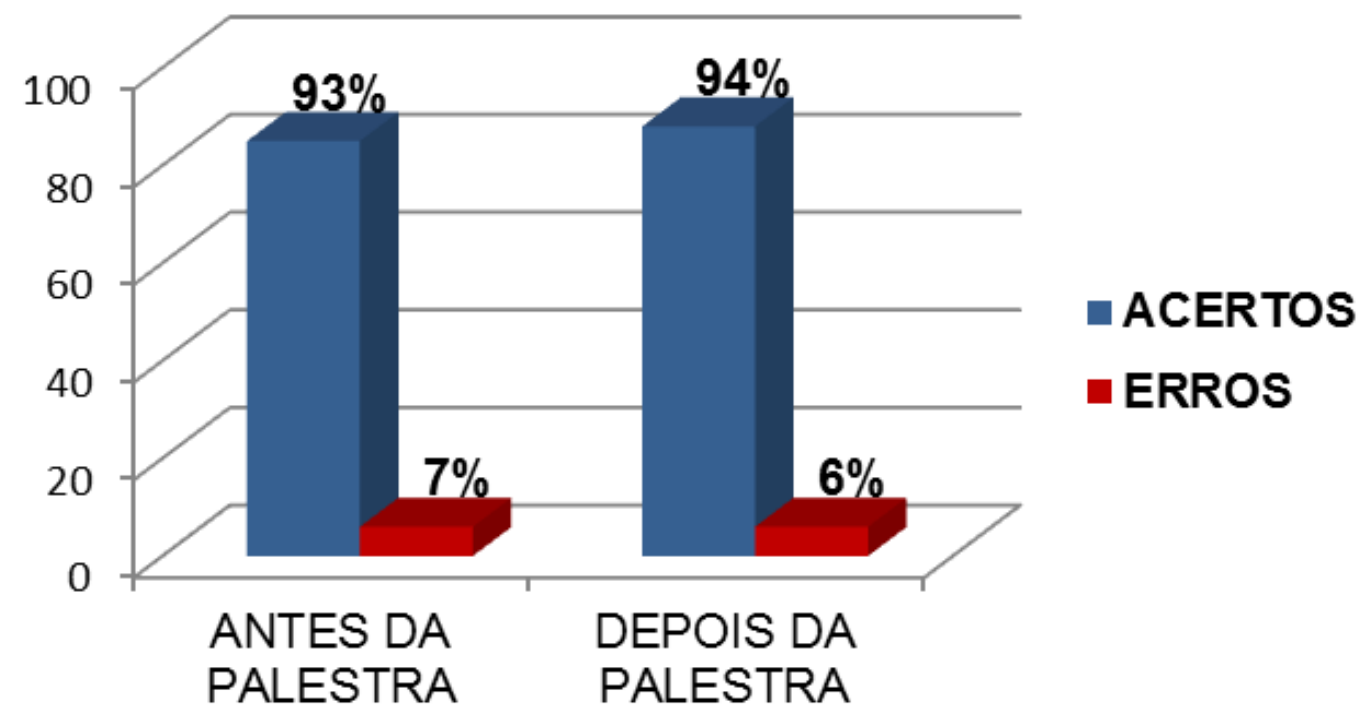

Fonte: Os autores, 2018

Após a palestra, houve uma melhoria na compreensão, mas é visível que os estudantes também já tinham um conhecimento prévio a respeito de como deve ser realizada a separação dos resíduos recicláveis e do lixo orgânico após serem utilizados.

$\mathrm{Na}$ pergunta oito, com o intuito de verificar se os alunos têm o conhecimento do que acontece com o lixo produzido na escola, foi realizado uma questáo de múltipla escolha, com as seguintes alternativas: a) Nada, é jogado no lixo para a coleta do caminhão de lixo; b) É aproveitado para a reciclagem; c) É queimado.

As respostas para esta questáo encontram-se na figura 9.

É possível notar o aumento do número das respostas relacionadas à queima do lixo, fato que lamentavelmente ocorre com o lixo da escola. Embora isso esteja conceitualmente incorreto, é uma resposta, portanto, muito cabível dentro do contexto da regiáo. Assim, os alunos que marcaram a opçáo que dizia que o lixo era queimado, de fato acertaram, visto que o lixo realmente foi queimado em larga escala cerca de dois dias antes da aplicação do segundo questionário. Além disso, grande parte da comunidade escolar trabalha em olarias e fábricas de cerâmica, de modo que o lixo é comumente utilizado como combustível nos fornos desses locais.

A pergunta da questão nove do questionário teve como objetivo de analisar se há separação de lixo reciclável nas casas dos estudantes e qual o destino é dado a esse lixo. As alternativas foram: a) Queimado, b) Coletores de lixo de rua, c) Coleta seletiva, d) Doado para catadores de lixo; e) Não há separação; f) Outros. Os resultados obtidos para esta pergunta encontram-se na figura 10 .

Por último, na questão dez, foi realizada uma questão aberta com o objetivo de provocar os alunos em relaçáo à reciclagem, perguntando se eles acreditavam que para reduzir a quantidade de lixo no planeta, reciclar era o suficiente. As respostas encontram-se tabuladas na figura 11: 
Figura 9 - Resposta para a pergunta 8: "Você sabe o que acontece com o lixo na sua escola?"

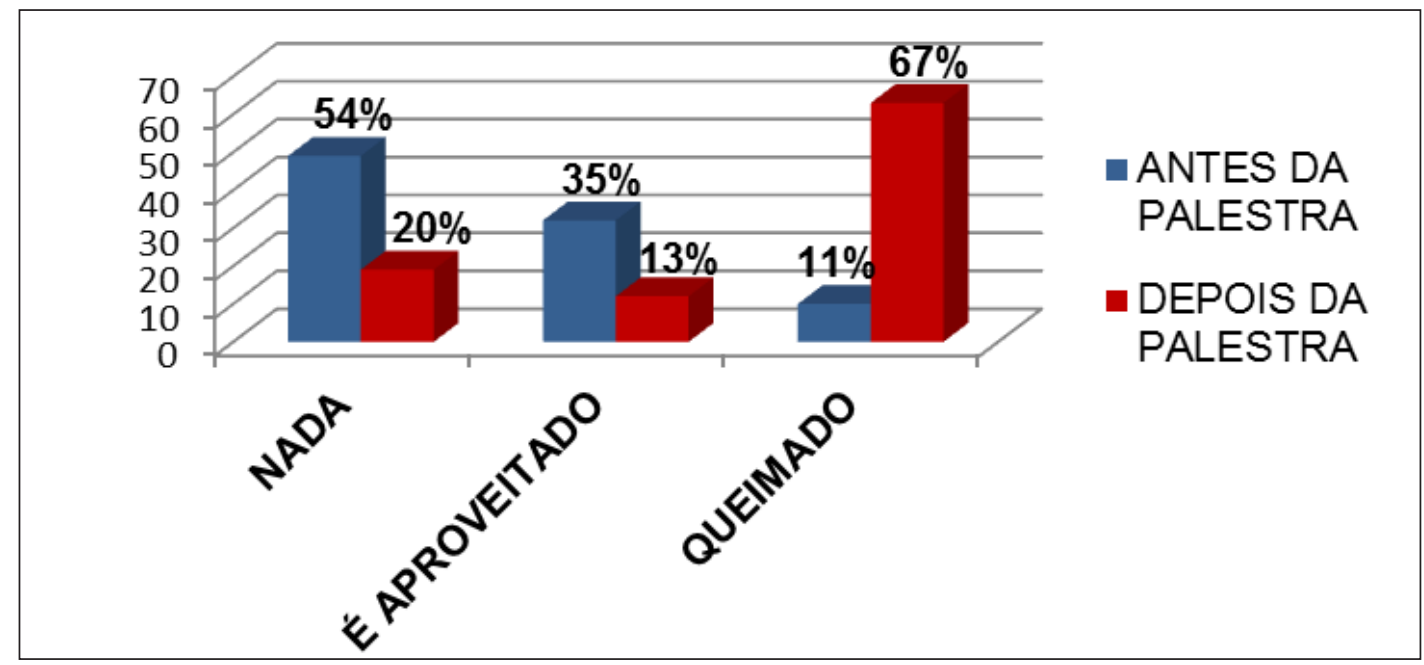

Fonte: Os autores, 2018

Figura 10 - Resposta para a pergunta 9: "Se há separação de lixo reciclável em sua casa, qual o destino é dado?”

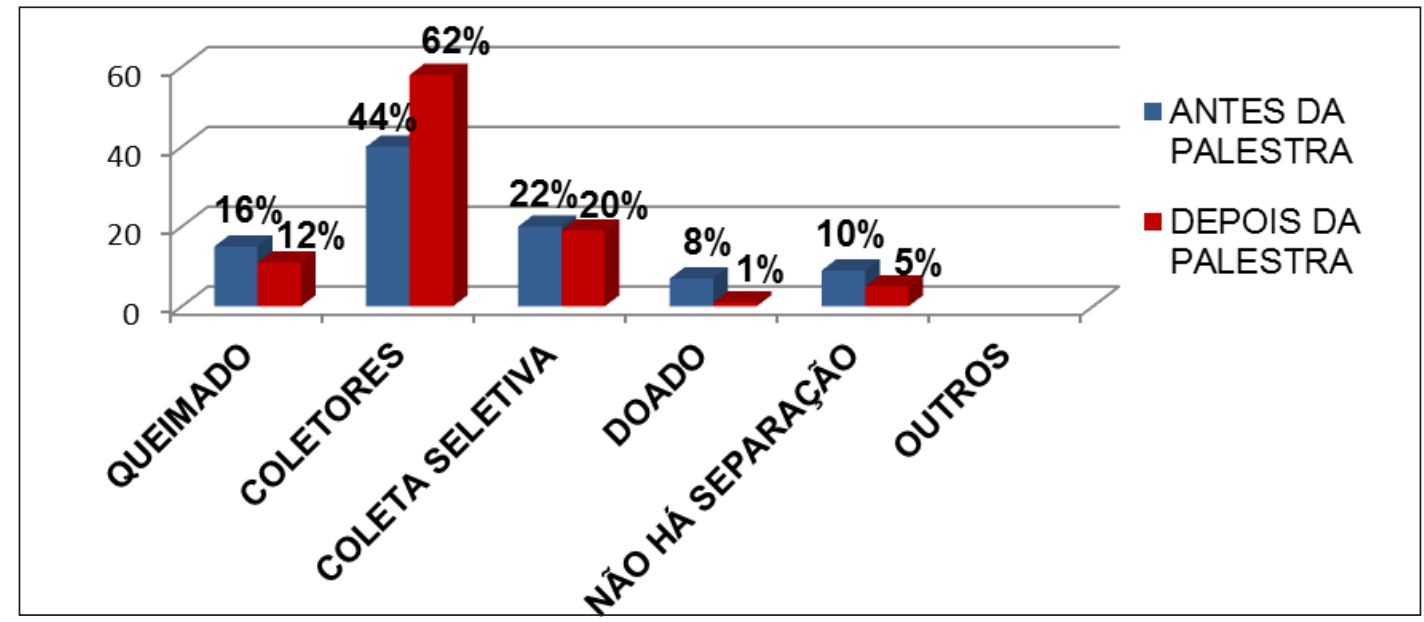

Fonte: Os autores, 2018

Figura 11 - Resposta para a pergunta 10: "Reciclar é o suficiente para reduzir a quantidade de lixo no planeta?"

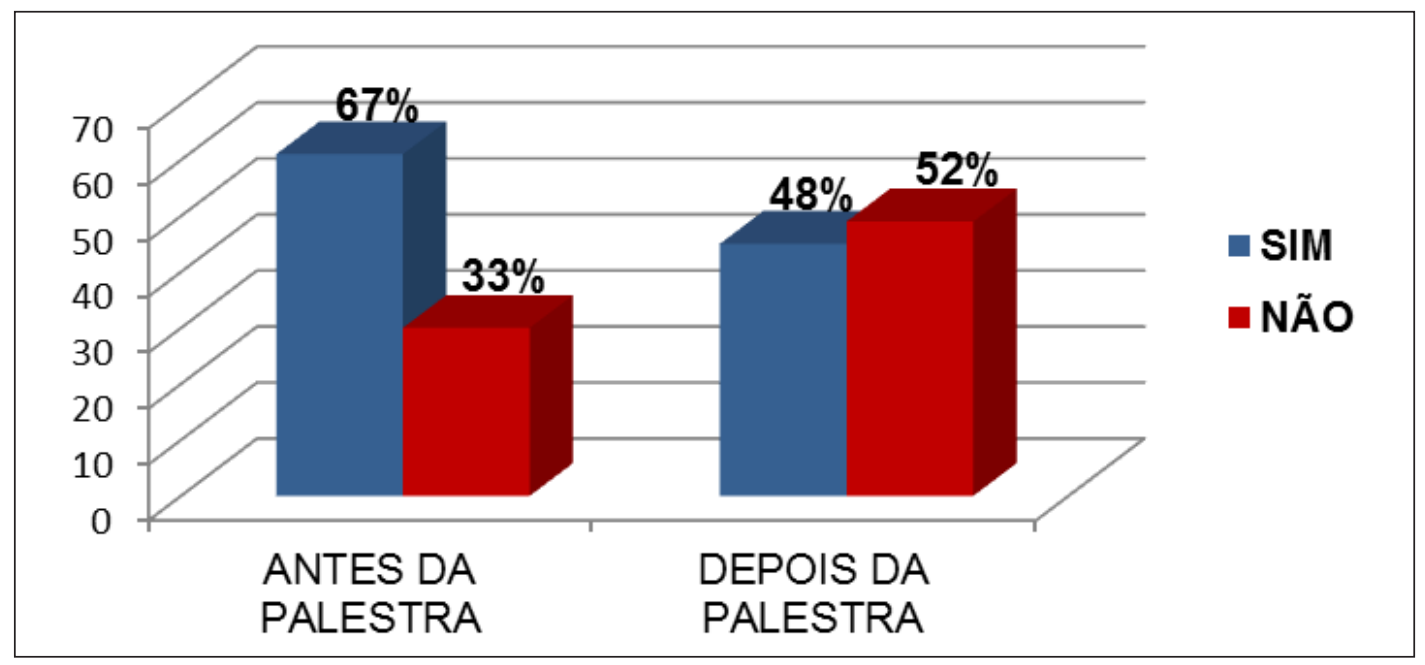

Fonte: Os autores, 2018 
A resposta que se esperava para essa questấo era realmente não; foi significante este aumento o que mostra que houve uma melhoria na compreensão dos alunos após a palestra, estes perceberam que apenas reciclando não é o suficiente para reduzir a quantidade de lixo no planeta, é precisando também diminuir o consumo de água, entre outros problemas que afetam o planeta.

Como não foi feito um pareamento cuidadoso e uma escolha mais criteriosa dos estudantes, optou-se pelo trabalho mais descritivo para náo se incorrer em um erro estatístico. Dentre os assuntos trabalhados, a palestra tratou predominantemente sobre como deve ser feita a coleta seletiva do lixo, a qual implica na separaçáo por tipo de material descartado e que deve ser depositado em latóes de cores diferentes: azul (papel), vermelho (plástico), verde (vidro), amarelo (metal), preto (não reciclável (Figura 12).

Figura 12 - Símbolos e cores referentes à destinação correta de lixo

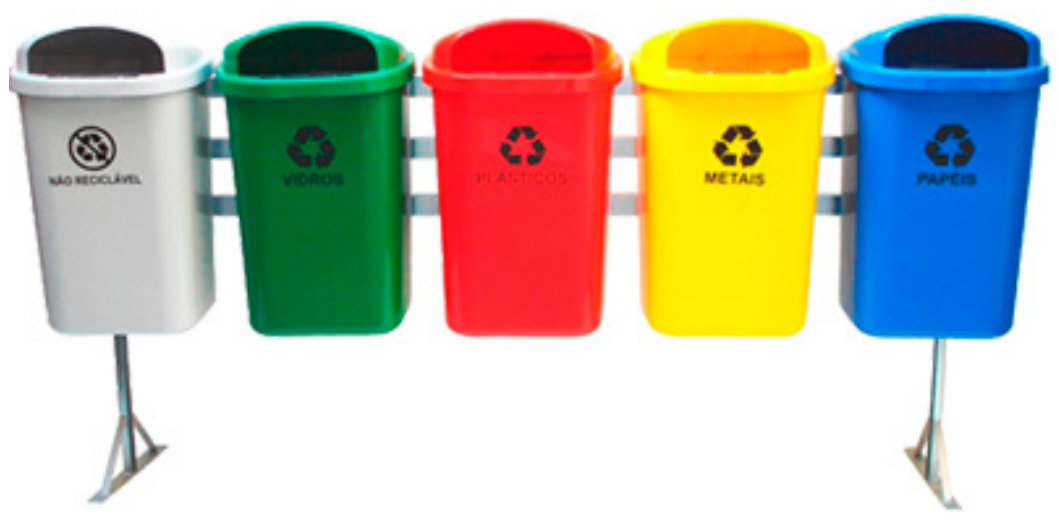

Fonte: Portal TJSC, 2016

Os questionamentos realizados durante a palestra foram relacionados sobre o que é o lixo, para onde ele vai, o que é compostagem, assim interagindo com os alunos, fazendo-os ter curiosidade sobre o tema abordado. As discussóes e diálogos realizados em sala de aula envolveram os alunos através de comentários e de suas experiências sobre reciclagem realizadas na escola, comunidade ou dentro de suas casas. O objetivo é fazer o aluno colocar em prática o tema abordado e se conscientizar sobre a importância da preservação do meio ambiente.

Finalmente, foi proposto que os alunos fizessem um jogo a respeito dos temas abordados. A utilizaçáo de jogos didáticos surge como uma ferramenta de ensino capaz de despertar a curiosidade, o interesse e a criatividade, além de motivar o aluno para a participação em sala de aula.

Foram montados 24 jogos no total, sendo 12 no $7^{\circ}$ ano e 6 em cada turma do $6^{\circ}$ ano. Os jogos mais comuns foram os que estão de alguma forma, relacionados à prática esportiva. Assim, 10 jogos eram relacionados a futebol de botão, boliche, basquete, entre outros. Um exemplo desse jogo pode ser visto na figura 13.

Figura 13 - Representação de um jogo de futebol de botão com materiais recicláveis

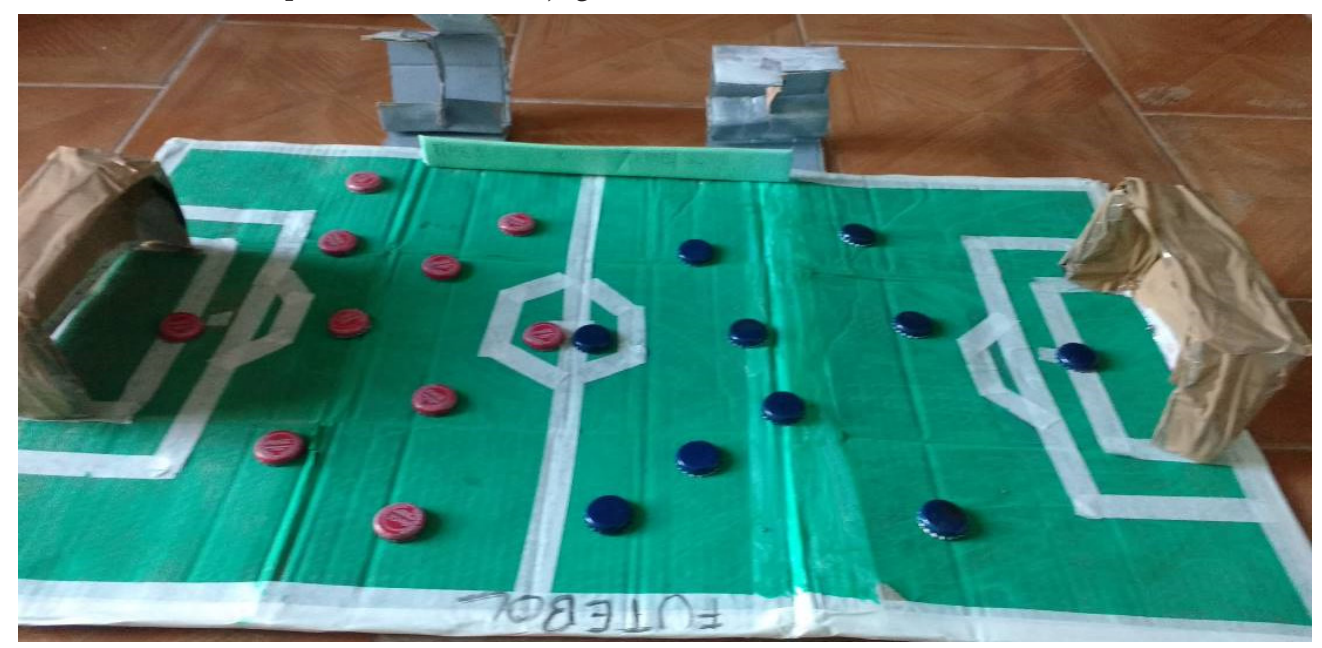

Fonte: Os autores, 2018 
Foram montados cinco jogos de tabuleiro "clássicos", como xadrez, trinca, jogo da velha, entre outros. Exemplos desses jogos podem ser vistos nas figuras 14 e 15.

Figura 14 - Representação de um jogo de xadrez com materiais recicláveis

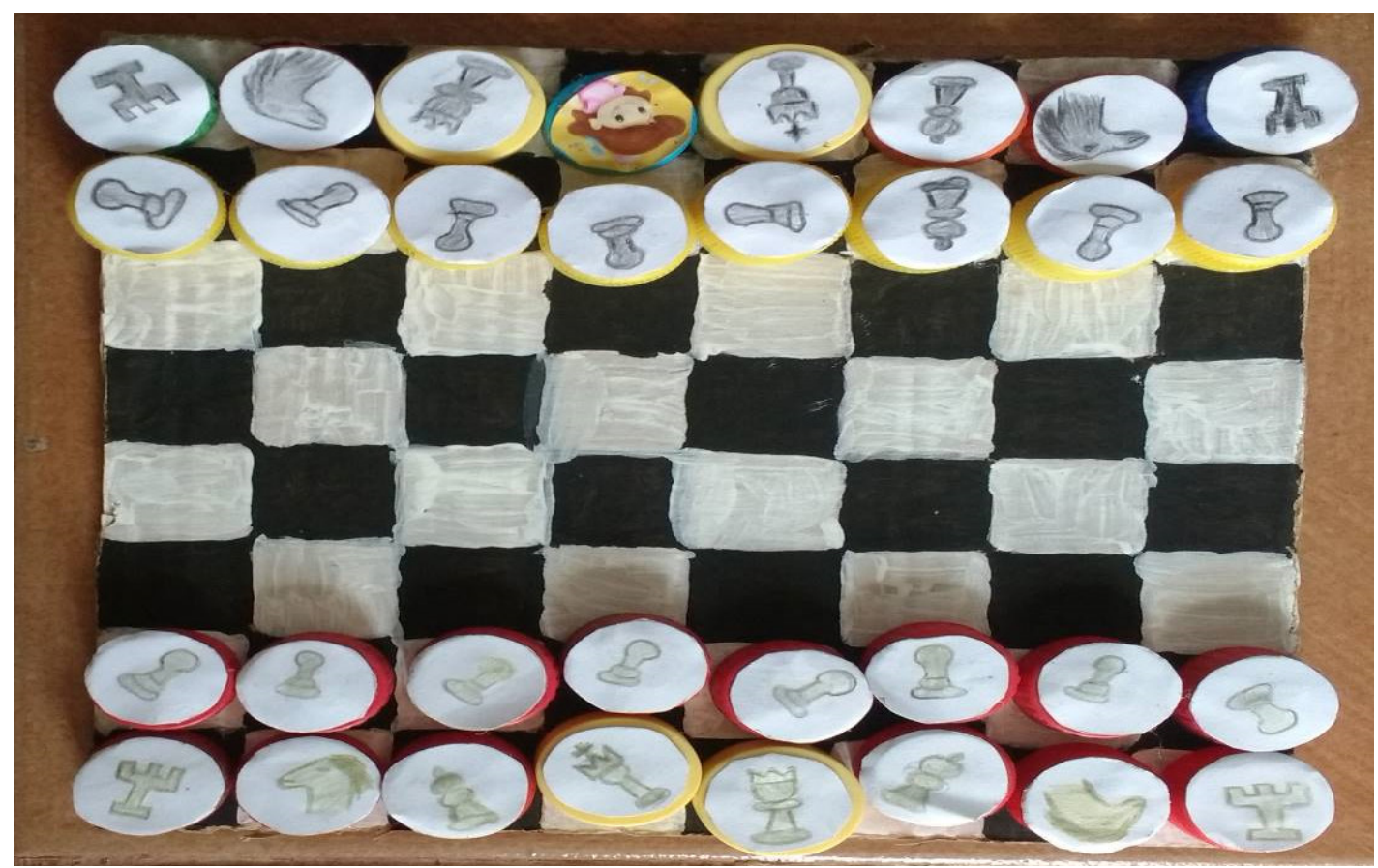

Fonte: Os autores, 2018

Figura 15 - Representação de um jogo de trinca com materiais recicláveis

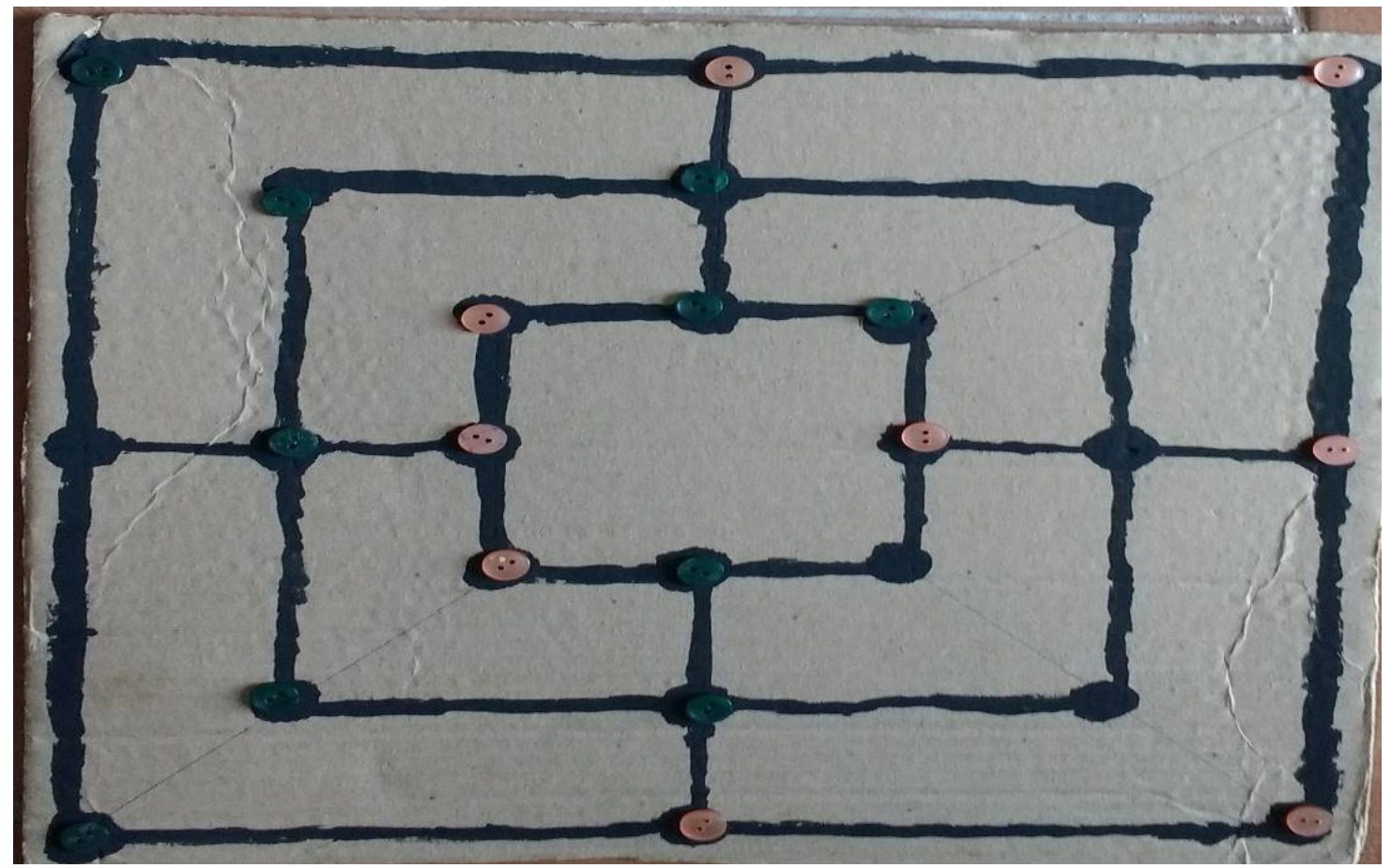

Fonte: Os autores, 2018 
Houve jogos que não se encaixam em nenhuma das categorias pré-estabelecidas, como um "cara-a-cara" e um "cai-cai" (Figura 16).

Figura 16 - Representação de um jogo "cara-a-cara” e de um "cai-cai” com materiais recicláveis.
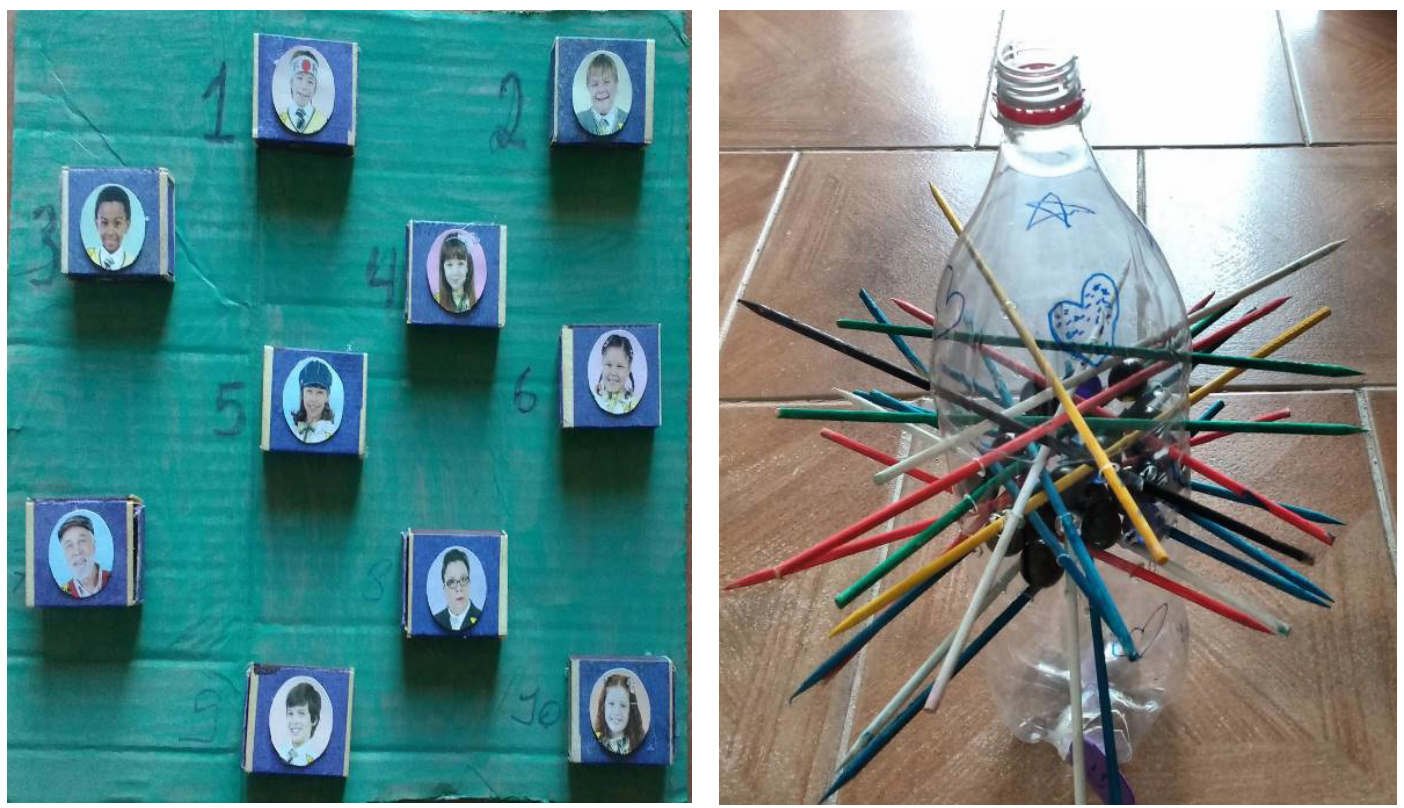

Fonte: Os autores, 2018

Esses jogos, embora tenham seu valor lúdico, demonstram que os alunos não compreenderam corretamente os conceitos passados na cartilha e na palestra. A ideia de pegar um material que seria jogado fora e, com ele, fazer um jogo ou outro objeto artesanal, não está corretamente relacionada à ideia de reciclagem. Assim, o objetivo do jogo $71 \%$ dos jogos apresentados ainda apresenta uma visáo incorreta de reciclagem.

Essa confusão entre reuso e reciclagem é bastante comum, inclusive nas escolas. Embora, em nenhum momento tenha se dito que os jogos deveriam ser de determinada maneira, foi reforçado muitas vezes que o tema era reciclagem. Assim, embora, como demonstrado anteriormente, tenha havido uma melhoria conceitual nas respostas do questionário, alguns equívocos sobre esse tema ainda permanecem nos conceitos dos alunos.

Sete jogos (29\%), no entanto, demonstraram uma compreensão melhor sobre o tema e realmente fizeram jogos que atenderam o objetivo proposto. Cinco jogos eram jogos de percurso, atrelados a perguntas e respostas sobre o tema. Exemplos desses jogos podem ser vistos na figura 17.

Figura 17 - Representação de um jogo de percurso, com materiais recicláveis.

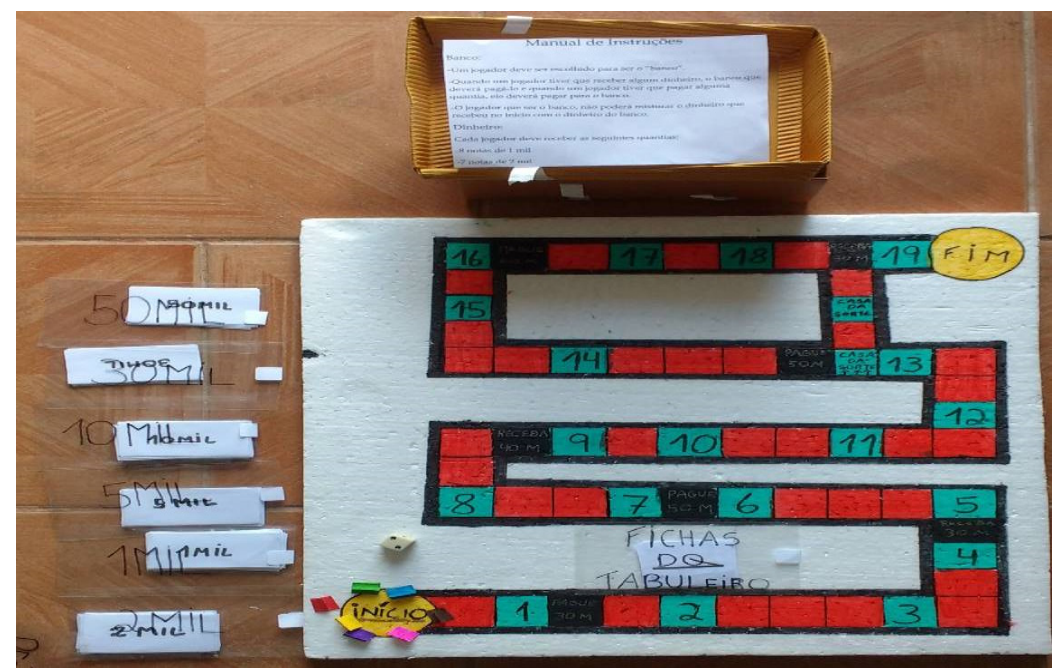

Fonte: Os autores, 2018. 
Um dos jogos que mais chamou a atenção foi uma espécie de "pinball", onde havia seis lixos, cada uma representando: vidro, metal, plástico, papel, lixo orgânico e não reciclável. Um jogador escolhia três destes lixos, e o outro jogador deveria encaixar corretamente a bola de gude nestes lixos escolhidos pelo outro jogador, caso este errasse as latas escolhidas haveria penalidades, como a perda de alguns pontos. Ganharia o jogo quem acertasse as latas e fizesse mais pontos. Esse jogo pode ser visto na figura 18.

Figura 18 - Representação de um jogo de "pinball”, com materiais recicláveis.

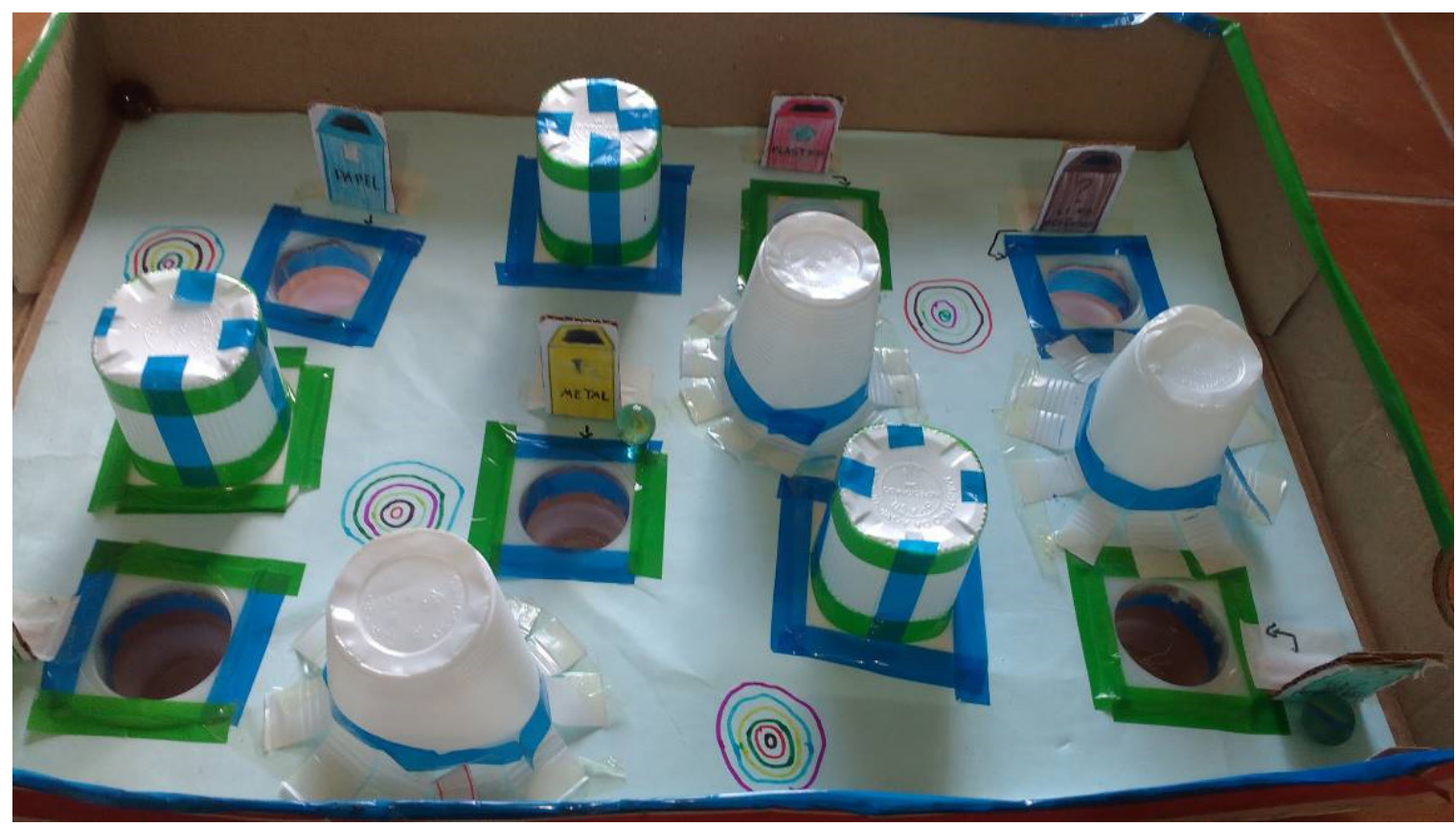

Fonte: Os autores, 2018.

Figura 19 - Representação de um jogo de latas, com materiais recicláveis.

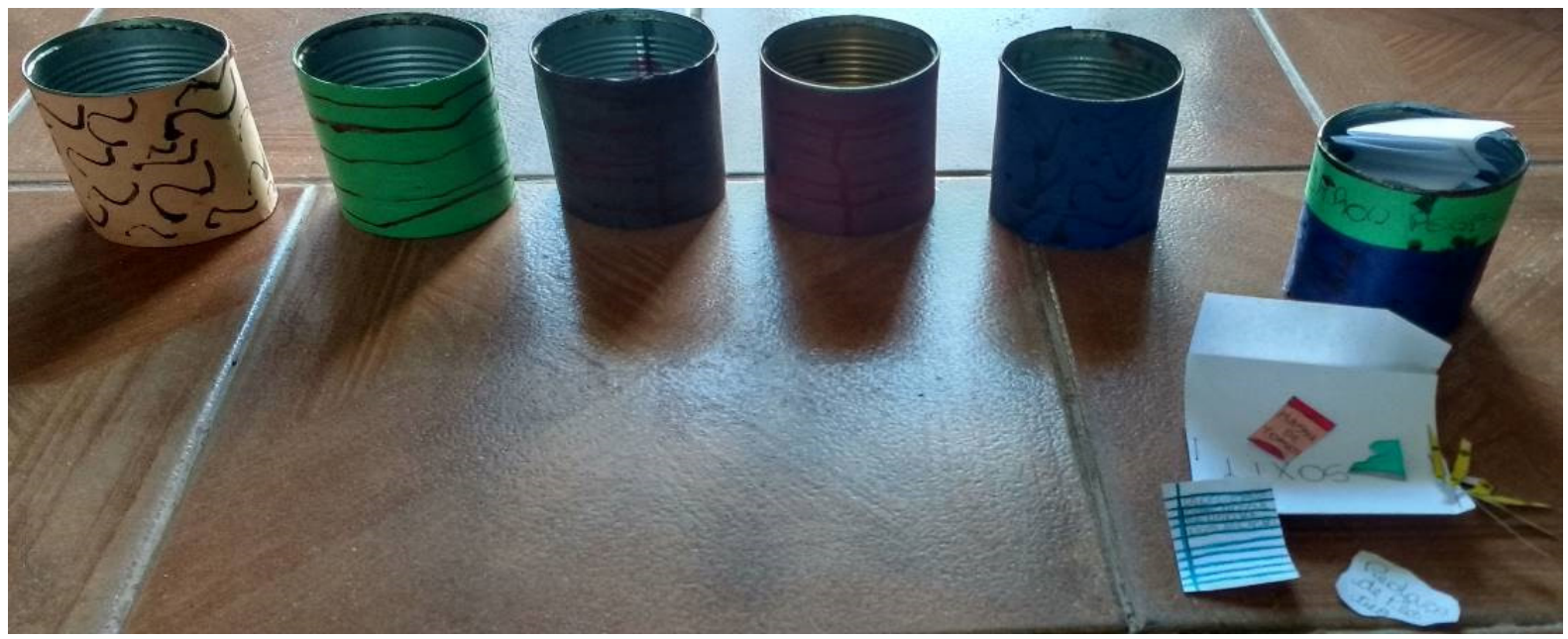

Fonte: Os autores, 2018.

Finalmente, o jogo que mais atendeu a proposta, foi um jogo que envolvia cinco latas pintadas corretamente e cartas representando diferentes tipos de lixo. O objetivo era que, uma vez que tirasse a carta, o jogador a "jogasse" no lixo correto. Em caso de erro, havia outra lata com "castigos" como punição para o erro. A imagem desse jogo pode ser vista na figura 19. 


\section{CONCLUSÕES}

A Educação Ambiental na escola é fundamental e de extrema importância para a formação de cidadãos conscientes e comprometidos com o Meio Ambiente. Através das mudanças de hábitos e da informaçáo, é possível à melhoria do planeta e da qualidade de vida associada à melhores condiçóes ambientais. A ação educativa, realizada em uma escola da Rede Estadual do Paraná surtiu efeito na compreensão dos conceitos relacionados à reciclagem e conservação do Meio Ambiente através das mudanças de atitudes e sensibilização imediata dos alunos.

Conclui-se, contudo que houve uma diferença entre o questionário aplicado após a palestra e a compreensão demonstrada no jogo didático. Ainda que o resultado no questionário aplicado após as intervençóes didáticas tenha sido muito melhor, ainda há uma confusão grande entre os conceitos de reciclagem e reutilização; infelizmente, ainda é comum a ideia de se pegar um material que seria jogado fora e com ele fazer algo artesanal, um jogo, entre outros como o conceito de reciclagem.

A sensibilização é um trabalho árduo e contínuo. Assim, mais trabalhos dessa natureza, com uma amostra maior e com outras abordagens pedagógicas são extremamente necessários para a efetivação do conceito de reciclagem e dos efeitos ambientais correlatos.

\section{REFERÊNCIAS}

ABRELPE - Associação Brasileira de Empresas de Limpeza Pública e Resíduos Especiais. (2008). Panorama dos resíduos sólidos no Brasil 2007. São Paulo, 2008. Disponível em: http://www.abrelpe.org.br/Panorama/panorama2007.pdf . Acesso em: 01 de abril de 2018.

ABRELPE - Associaçăo Brasileira de Empresas de Limpeza Pública e Resíduos Especiais. (2017). Panorama dos resíduos sólidos no Brasil 2016. São Paulo, 2017. Disponível em: http://www.abrelpe.org.br/Panorama/panorama2016.pdf. Acesso em: 01 de abril de 2018.

ANTQUEVES, L.M., BOSA, C. R., SILVA, J. D. (2015). A Educação Ambiental e atividades lúdicas: um incentivo na mudança de hábitos na geração de lixo. Revista Monografias Ambientais, 14 (2), 192p. Disponível em: https://periodicos.ufsm.br/remoa/ article/view/18806. Acesso em 19 de fevereiro de 2018.

BRASIL. Lei no 12.305, de 2 de agosto de 2010. Institui a Política Nacional de Resíduos Sólidos; altera a Lei no 9.605, de 12 de fevereiro de 1998; e dá outras providências.

BRUM, D. P., SILVEIRA, D. D. (2011). Educação ambiental na escola: da coleta seletiva do lixo ao aproveitamento do resíduo orgânico. Revista eletrônica em Gestão, Educação e Tecnologia Ambiental, 4(4), 608p. Disponível em: http://periodicos.ufsm.br/ reget/article/view/3909/0. Acesso em 19 de fevereiro de 2018.

CABRAL, F. F., RIBEIRO, I. R., HRYCYK, M. F. (2015). Percepção ambiental dos alunos de $6^{\circ}$ ano de escolas públicas. Revista Monografias Ambientais, 14 (2), 161p. Disponível em: https://periodicos.ufsm.br/remoa/article/view/18392 . Acesso em 19 de fevereiro de 2018.

CARVALHO, V. S. (2002). Educação ambiental e desenvolvimento comunitário. Rio de Janeiro: Wak.

CEMPRE (2013). Compromisso Empresarial para a Reciclagem. Review. Disponível em: http://www.cempre.org.br/ download CEMPRE_review_2013.pdf. Acesso em: 19 de fevereiro 2018

DIAS, G. F. (1994). Educação ambiental: princípios e práticas. São Paulo: Gaia.

FALKEMBACK, G. A. M. (2006). O lúdico e os jogos educacionais. Monografia, Universidade Federal do Rio Grande do Sul.

FAZENDA, I. C. (1993). A Interdisciplinaridade: um projeto em parceria. São Paulo: Loyola

FILHO, S. T., MACHADO, C. J. S., VILANIS, R. M..], PAIVA, J. L., MARQUES, M. R. D. C. (2015) A Logís- 
tica Reversa e a Política Nacional de Resíduos Sólidos: desafios para a realidade brasileira. Revista Eletrônica em Gestấo, Educação e Tecnologia Ambiental, 19(3) 529-538. Disponível em: https://periodicos.ufsm.br/reget/article/ viewFile/19322/pdf. Acesso em: 23 de fevereiro de 2018.

FREIRE, J. B. (2002). Educação de corpo inteiro. São Paulo.

GUERRA, S. (2009). A crise ambiental na sociedade de risco. Revista Eletrônica Lex Humana, no 2, p. 177-215. Disponível em: http://seer.ucp.br/seer/index.php/LexHumana/article/viewFile/27/26. Acesso em 01 de abril de 2018.

JACOBI, P. R. (2005). Educação Ambiental: o desafio da construção de um pensamento crítico, complexo e reflexivo. Monografia, Universidade de São Paulo.

LEONARD, A. (2011) A História das coisas: da natureza ao lixo, o que acontece com tudo o que consumimos. Rio de Janeiro, Zahar. Disponível em: https://www.youtube.com/watch?v=7qFiGMSnNjw. Acesso em 25 de fevereiro de 2018

MACEDO, L., PETTY, A. L. S., \& PASSOS, N. C. (2009). Os jogos e o lúdico na aprendizagem escolar. Artmed Editora.

MADEIRA, K. S. L; BARBOSA, S. (2009). A importância da Educação Ambiental na escola para formação do cidadão. Monografia, Instituto Federal do Piauí.

MARANHÃO, N. (2016). Meio Ambiente: descrição Jurídico Conceitual. Revista Magister de Direito Ambiental e Urbanístico. 11 (66), 70p. Disponível em: http://bdjur.stj.jus.br/jspui/handle/2011/104783. Acesso em 25 de fevereiro de 2018 .

MARQUES, M. L. A. P., SILVA, A. F., ARAÚJO, J. E. Q., QUEIROZ, T. H. S., ALMEIDA, I. D. A., MARINHO, A. A. (2004). A Educação Ambiental na formação da consciência ecológica. Semina, 1 (1), 18p.Disponível em: https:// periodicos.set.edu.br/index.php/fitsexatas/article/view/1336. Acesso em 25 de fevereiro de 2018.

MEDEIROS, A. B., MENDONÇA, M. J. S. L., SOUSA, G. L., OLIVEIRA, I. P. ET AL. (2011a). A importância da educação ambiental na escola nas séries iniciais. Revista Faculdade Montes Belos, 4(1), 17p. Disponível em: http://www. terrabrasilis.org.br/ecotecadigital/pdf/a-importancia-da-educacao-ambiental-na-escola-nas-series-iniciais.pdf. Acesso em 25 de fevereiro de 2018.

MEDEIROS, M. C. S., RIBEIRO, M. C. M., FERREIRA, C. M. A. (2011b). Meio Ambiente e educação ambiental nas escolas públicas. Revista Âmbito Jurídico, 14 (92), 6p. de http://www.ambito-juridico.com.br/site/index.php?artigo_ id=10267\&n_link=revista_artigos_leitura. Acesso em 25 de fevereiro de 2018.

MELZER, D., HARRIES, L., CIPELLI, R., HENLEY, W., MONEY, C., MCCORMACK, P. et al., (2011). Bisphenol A Exposure Is Associated with in Vivo Estrogenic Gene Expression in Adults. Environ Health Perspect. 119 (12), 1p. Disponível em: https://ehp.niehs.nih.gov/1103809/ . Acesso em 25 de fevereiro de 2018.

MINISTÉRIO DA EDUCAÇÃO E DESPORTO. Secretaria de Educação Fundamental. (1997). Parâmetros curriculares nacionais: meio ambiente e saúde. Brasília, DF

MINISTÉRIO DO MEIO AMBIENTE (2005). Consumo Sustentável. Disponível em: http://www.mma.gov.br/estruturas/educamb/_arquivos/consumo_sustentavel.pdf. Acesso em: 23 de fevereiro de 2018.

MINISTÉRIO DA EDUCAÇÃO. Secretaria de Educação Continuada, Alfabetização e Diversidade. (2012). Proposta de Diretrizes Curriculares Nacionais para a Educação Ambiental. Brasília, DF.

MINISTÉRIO DO MEIO AMBIENTE. Produção de Consumo Sustentáveis. (2012). Princípio dos 3R’s. Brasília, DF.

MIRANDA, F. H. F., MIRANDA. J.A, RAVAGLIA. R. (2010). Abordagem Interdisciplinar em Educação Ambiental. 
REVISTA PRÁXIS, 2 (4), 16p. Disponível em: http://web.unifoa.edu.br/revistas/index.php/praxis/article/view/922 Acesso em 25 de fevereiro de 2018.

OKIDA, R. J. (2006). Estudo para a minimizaçẫo e reaproveitamento de resíduos sólidos de fundiçấo, Dissertação (Pós-Graduação). Universidade Tecnológica Federal do Paraná, 2006.

OLIVEIRA, N. A. S. (2006). A percepção dos Resíduos Sólidos (lixo) de origem domiciliar no Bairro Cajuru, Curitiba-PR: um olhar reflexivo a partir da educação Ambiental, Dissertação (Mestrado em Geografia). Universidade Federal do Paraná. Curitiba, 2006.

OliVEIRA, G. C. P; ARAÚJO, J. V.; SILVA, V.; JUNIOR, A. M. C.; PALOMBIT, K.(2017) Bisfenol A: Possíveis Efeitos e Danos ao Organismo - Revisão de Literatura. Jorn. Inter. Bioc. 2 (2), p. 11-16.

PINTO, L. T. (2009). O uso dos jogos didáticos no ensino de ciências no primeiro segmento do ensino fundamental da rede municipal pública de Duque de Caxias, Dissertação (Mestrado em Ensino de Ciências) Instituto Federal de Educação, Rio de Janeiro.

PRESIDÊNCIA DA REPÚBLICA. Casa Civil (2010). Lei no 12.305, de 2 de agosto de 2010. Brasília, DF.

REIS, M. F. C. T. (2008). Pesquisa-ação em Educação Ambiental. Revistas USP, 3(1), 155p. Disponível em: www.revistas.usp.br/pea/article/download/30044/31931. Acesso em 22 de fevereiro de 2018.

REIS, L. C. L., SÊMEDO, L. T. A. S., \& GOMES, R. C. et al. (2012) Conscientização ambiental: da Educação formal a não formal. Revista Fluminense de extensão universitária, 2(1), 47p. Disponível em: http://www.uss.br/pages/revistas/ revistafluminense/v2n12012/pdf/005-Ambiental.pdf. Acesso em 22 de fevereiro de 2018.

RODRIGUES, C. M., BORILLE, D. R. G., SILVA, L. D., FERNANDES, G. N. S (2013). A conscientização das crianças no ambiente escolar: reciclar para preservar. Monografia, Universidade do Rio Verde, Goiás.

RODRIGUES, R. M. (1997). Ecologia em debate. São Paulo: Moderna.

SECRETARIA DE GESTÃO AMBIENTAL. Poder Judiciário de Santa Catarina. (2014). Coleta Seletiva. Florianópolis, SC. Disponível em https://portal-h.tjsc.jus.br/web/sga/coleta-seletiva. Acesso em 25 de fevereiro de 2018.

SILVA, S.; FERREIRA, E.; ROESLER, C.; BORELLA, D.; GELATTI, E..; BOELTER, F.; MENDES, P. (2017). Os 5 R's Da Sustentabilidade. In: V Seminário de Jovens Pesquisadores em Economia \& Desenvolvimento (SJPE\&D), Santa Maria/RS. Anais do V SJPE\&D da UFSM. Disponível em: http://coral.ufsm.br/seminarioeconomia/images/ anais_2017/OS_5_RS_DA_SUSTENTABILIDADE_OS_5_RS_DA_SUSTENTABILIDADE_OS_5_RS_DA_SUSTENTABILIDADE_OS_5_RS_DA_SUSTENTABILIDADE_OS_5_RS_DA_SUSTENTABILIDADE_OS.pdf . Acesso em 19 do março de 2018.

SILVA, A. F.; LIMA, C. M. V. de; SANTOS, J. H.; SILVA, P. V. S.; SILVA, R. F (2013). Lixo eletrônico: como dar uma melhor destinação. Revista Acadêmica FEOL, 1(1), 71-90. Disponível em: http://177.8.219.7:8081/revista/index.php/ R1/article/view/31. Acesso em 01 de abril de 2018.

VASCONCELOS, A. P., VILAROUCA, J. (2010). Avaliação da percepção ambiental dos alunos da EMEIF Dagmar Gentil: Estudo de caso. Monografia, Instituto Federal de Educação, Fortaleza.

WOJCIECHOWSKI, T. S. (2006). Projetos de educaçáo ambiental no primeiro e no segundo ciclos do ensino fundamental: problemas socioambientais no entorno de escolas municipais de Curitiba. Dissertaçáo de Pós-graduação, Universidade Federal do Paraná, Curitiba. 